\title{
ISOTOPE GEOCHEMISTRY AND GEOCHRONOLOGY OF SYN-DEPOSITIONAL VOLCANISM IN Porongos Metamorphic Complex, Santana da Boa Vista Antiform, Dom FELICIANO BELT, BRAZIL: ONSET OF AN 800 MA CONTINENTAL ARC
}

\section{Leonardo Gruber ${ }^{1, *}$, Carla Cristine Porcher ${ }^{2}$, Edinei Koester ${ }^{2}$, Anelise L. Bertotti ${ }^{3}$, Cristine Lenz ${ }^{3}$, Luís Alberto D'Ávilla Fernandes ${ }^{2}$ AND MARCus Vinícius Dorneles Remus ${ }^{2}$}

1 Programa de Pós-graduação em Geologia da Universidade Federal do Rio Grande do Sul - Instituto de Geociências, Av. Bento Gonçalves, 9500, CEP 91501-970, Porto Alegre, RS, Brazil, leonardogruber@gmail.com

2 Departamento de Geologia, UFRGS, Av. Bento Gonçalves, 9500, CEP 91501-970, Porto Alegre, RS, Brazil, carla.porcher@ufrgs.br, koester@ufrgs.br, ladfernandes@gmail.com,marcos.remus@ufrgs.br

3 Núcleo de Geologia, UFS, Cidade Universitária Prof. José Aloísio de Campos, Av. Marechal Rondon, s/n, CEP 49100-000, Jardim Rosa Elze, São Cristóvão, SE, Brazil, aneber79@gmail.com, crislenz@yahoo.com.br

*CORRESPONDING AUTHOR, leonardogruber@gmail.com

Received on 23 March 2016

Received in revised form on 04 May 2016

Accepted on 05 May 2016

Editor:

Maria Virginia Alves Martins, Universidade do Estado do Rio de Janeiro,

Brazil

\section{Abstract}

The Porongos Metamorphic Complex (PMC) is composed of supracrustal rocks, predominantly pelitic micaschist, quartzite and felsic metavolcanic rocks. It represents the remnants of a Neoproterozoic sedimentary basin developed in the western Gondwana, now located in the central section of Dom Feliciano Belt in southern Brazil. Isotope signature comparison and $\mathrm{U}-\mathrm{Pb}$ ages shows that there are at least three main source-areas for the Porongos sediments: (i) one that can be related to Paleoproterozoic terrains; (ii) a younger component with Mesoproterozoic (1.5 - $1.2 \mathrm{Ga}$ ) ages; and (iii), a Neoproterozoic source with magmatic zircons $(0.8 \mathrm{Ga})$, with relative age distribution mostly between 1.7 and $1.0 \mathrm{Ga}, T_{\mathrm{DM}}$ ages between 2.58 and 1.71 $\mathrm{Ga}$, and younger ages of ca. 1.21 Ga, which can be related

\section{Introduction}

Understanding the tectonic evolution of Neoproterozoic mobile belts in South America depends heavily on accurate and robust geochronological and isotopic constraints, since much of the geological record is
Citation:

Gruber, L., Porcher, C.C., Koester, E., Bertotti, A.L., Lenz, C., Fernandes, L.A.D'A., Remus, M.V.D., 2016. Isotope geochemistry and geochronology of syndepositional volcanism in Porongos Metamorphic Complex, Santana da Boa Vista antiform, Dom Feliciano Belt, Brazil: Onset of an 800 Ma continental arc. Journal of Sedimentary Environments, 1(2): 196-215.

to 1.4 - 1.0 African signature sources. Ten concordant analysis obtained in zircon grains from a metarenite rock yield $206 \mathrm{~Pb} / 238 \mathrm{U}$ median age of $802+26 /-33 \mathrm{Ma}$, which is related to metavolcanic samples from PMC and correlates with the Neoproterozoic Cerro Bori Continental Arc, indicating a syn-depositional volcanism in the sedimentary record. The depositional setting for these sequences can be understood as an evolution between a passive margin developed after 1.6 Ga and a terrain-collisional setting (ca. $570 \mathrm{Ma})$.

Keywords: Porongos Metamorphic Complex. Dom Feliciano Belt. West Gondwana. Geochronology. Isotope Geochemistry. not preserved. The Neoproterozoic Dom Feliciano Belt (DFB) was formed by the interactions between the cratons Rio de la Plata (RdLP), in the west (Fig. 1A), Kalahari and Congo to the east (e.g. Fernandes et al., 1995a; Frantz et 


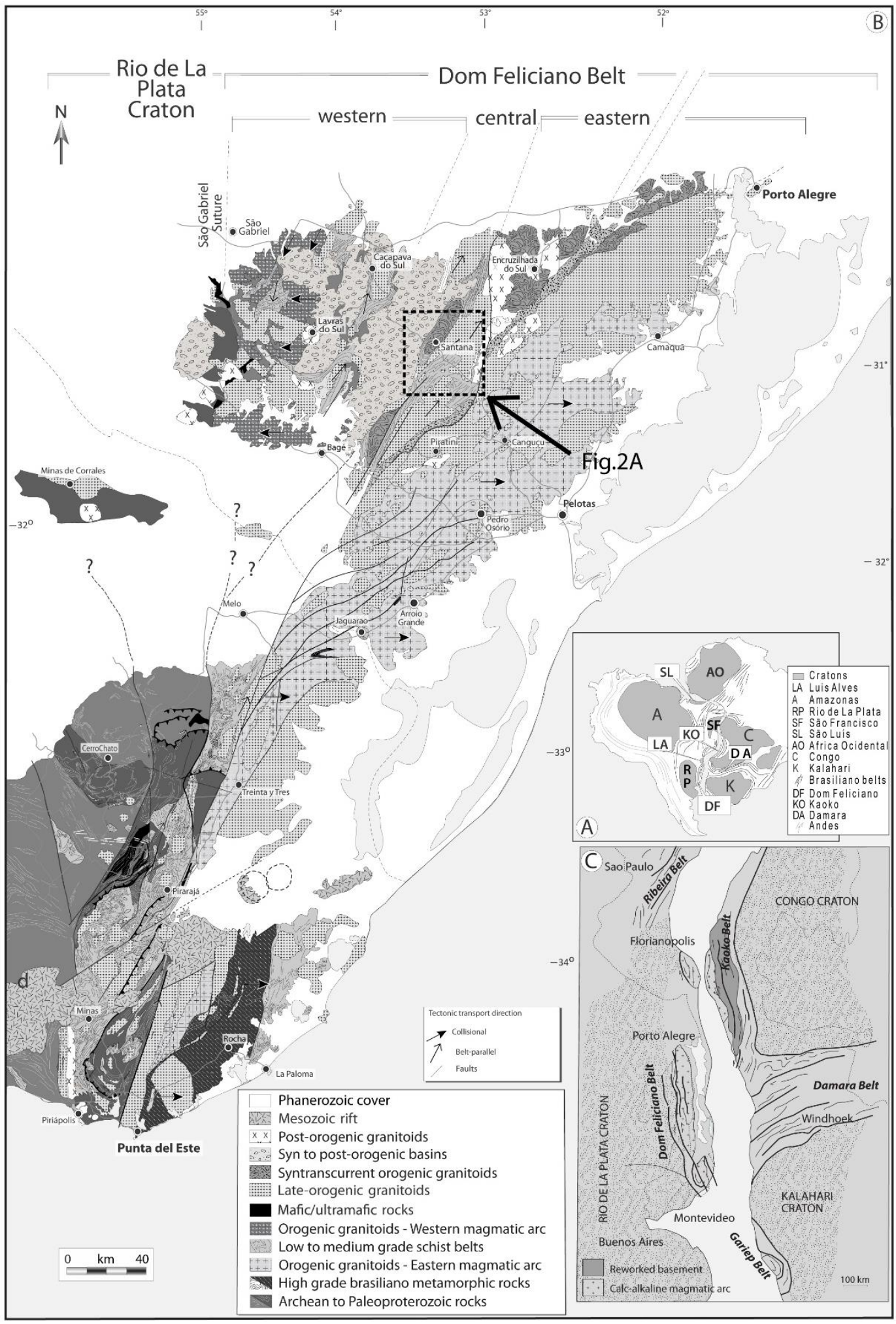

Fig. 1. A: Reconstruction of the Rio de La Plata, Kalahari and Congo cratons (modified from Fernandes et al., 1995a; Masquelin, 2000); B: Geological sketch map of the Dom Feliciano Belt, including PMC indicated by dotted line; C: Schematic geological map displaying the Pan-African belts in the Congo-Kalahari-Rio de La Plata convergence on the Gondwana formation. 
al., 1999; Chemale, 2000). The tectonic interactions between these three cratonic blocks have been intensively investigated (e.g. Basei et al., 2008; Saalmann et al., 2010; Rapela et al., 2011), and despite the controversies upon age of sedimentation, provenance and tectonic evolution raised by the different authors, it is clear that DFB represents one of the key areas to understand the assembly and evolution of west Gondwana during mid to late Neoproterozoic.

Studies have addressed several different aspects of the evolution of DFB, including: structural and geophysicalbased divisions on three domains (Fig.1B), the age of deposition of the post-collisional sedimentary sequences, age of metamorphism and emplacement of granite intrusions and evolution of its calc alkaline arc magmatism of Pelotas Batolith (Fig. 1C) (e.g. Fernandes et al., 1995a; Phillip and Machado, 2005; Borba et al., 2006; Basei et al., 2008; Saalmann et al., 2010; Rapela et al., 2011; Chemale et al., 2012). The metasedimentary rocks exposed in the three domains had also been investigated in various works (e.g. Basei et al., 2008; Gruber et al., 2011; Lena et al., 2014; Lopes et al., 2015; Pertille et al., 2015a; Pertille et al., 2015b).

The lithodemic units of the Porongos Metamorphic Complex (PMC) (Fig. 2A) are exposed along the central portion of the Dom Feliciano Belt. These comprise mainly phyllite, meta-psamites, meta-conglomerates, metasandstones, mica schist and quartz mylonite (mylonitic quartzites) with interbedded metaultramafic and metavolcanic rocks, marbles and minor amphibolites intruded by granitoids sheets, all deformed and metamorphosed under greenschist to amphibolite facies conditions (Jost and Bitencourt, 1980; Jost, 1982; Porcher and Fernandes, 1990; Remus et al., 1987, 1990, 1991). The sequences of quarzites were designed as Santana Formation, with maximum depositional ages of ca. $1.7 \mathrm{Ga}$ (Pertille et al., 2015b), coinciding with stabilization of Columbia's supercontinent. The metapelitic sequences (Arroio Areião, Cerro Cambará lithodemic units) displays a more incongruent maximum depositional age, thus being studied here in more detail.

The depositional age of schists are constrained between a minimum depositional age obtained from metavolcanic rocks of ca. $780 \mathrm{Ma}$ (Porcher et al., 1999), and maximum depositional age (younger detrital zircon ages) indicated by Gaussian peaks of ca. 570 - 620 Ma (Basei et al., 2008; Pertille et al., 2015b). Previous works considered the deposition age as ca. $880 \mathrm{Ma}$, as suggested by maximum depositional ages from Santana Formation (fm.). with U$\mathrm{Pb}$ detrital zircon ages (Hartmann et al., 2004; Saalmann et al., 2006; Pertille et al., 2015a), which could still hold significance, taking into account that different lithodemic units could have been deposited at different times.

Uncertainties in these depositional ages have resulted in different interpretations about evolution of PMC and, therefore, these same uncertainties remain to the central part of the DFB, including diachronism of volcanic events and sedimentary deposition on the passive/rifting margins of Congo/Kalahari and RdLP cratons.

We present data on whole-rock $(\mathrm{Sm}-\mathrm{Nd}, \mathrm{Pb}-\mathrm{Pb})$ and qualitative zircon $\mathrm{U}-\mathrm{Pb}$ detrital zircon ages of one sample from a metarenite, which may help to unravel provenance and source-areas already discussed in other works (Saalmann et al., 2010; Basei et al., 2011; Gruber et al., 2011; Pertille et al., 2015a; Pertille et al., 2015b), besides the possibility of a syn-depositional volcanism in the vicinity of the PMC paleobasin, and its implications to paleoreconstructions of DFB.

\subsection{Geological setting}

The PMC crops out in the Central Domain (Fernandes et al., 1995a) (Fig. 2A) of the DFB in Rio Grande do Sul state. The DFB is the southern Brazil part of a long and discontinuous Neoproterozoic orogenic belt (Fig. 1B and C). It can be resumed as follows: from west (proximal to $\mathrm{La}$ Plata craton) to east (Atlantic margin) are the São Gabriel Block, composed of juvenile calk-alcaline granitoids and metasedimentary sequences deposited in a back-arc system (Hasui et al., 1975; Almeida et al., 1981; Hartmann et al., 2000; Saalmann et al., 2005); east of São Gabriel Block stands the Camaquã Basin, a late-to-post orogenic faultbonded basin with development in the late Neoproterozoic (Borba et al., 2006). The most prominent tectonic domain of DFB is the Pelotas Batholith, composed of six granite suites and small exposures of granitic-gneissic complexes and Paleoproterozoic basement (Phillip and Machado, 2005).

In the Rio Grande do Sul district, the DFB can be divided in three major tectonic domains (Fernandes et al., 1995a; Fernandes et al., 1995b) (Fig. 1B): (i) the western domain, separated from the central domain by the Caçapava Suture, is interpreted as a magmatic arc with juvenile crust and tectonically interleaved with remnants of ophiolites and supracrustal rocks. It is separated from the Rio de La Plata craton by the São Gabriel Suture (Fernandes et al., 1995b); (ii) the central domain is composed by palaeoproterozoic rocks interpreted as a tectonically reworked segment of the Rio de La Plata Craton. It was separated from the mainland during the opening of a marginal basin which widening evolved into 
the Charrua Sea (Fragoso-César, 1991); and (iii) the eastern domain is composed of calc-alkaline orogenic granitoids interpreted as part of a Neoproterozoic continental-margin magmatic arc and is separated from the central domain by the Porto Alegre Suture, a major gravimetric and magnetometric anomaly.
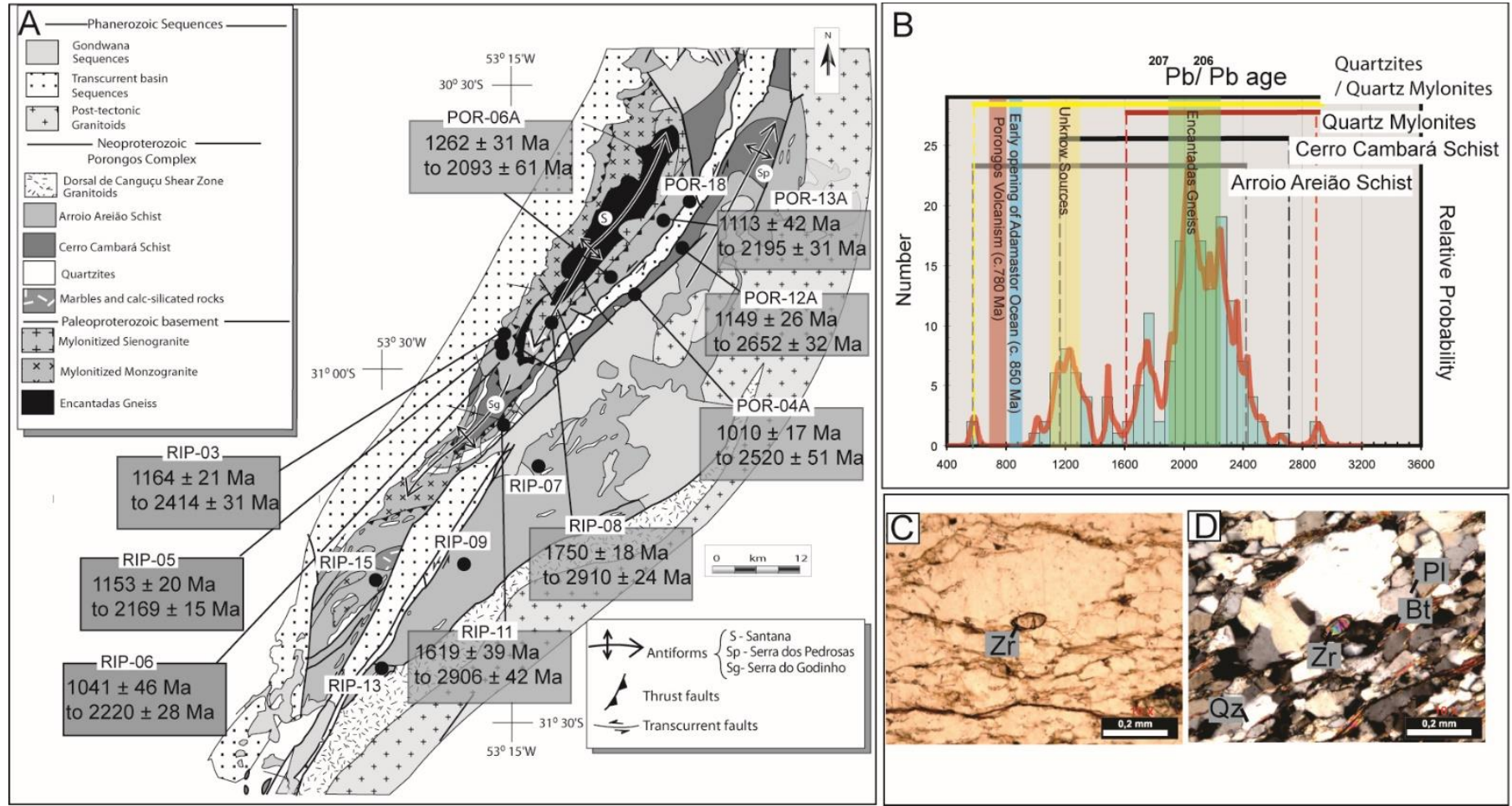

Fig. 2. A: Schematic geological map of the Porongos Complex (modified from Porcher and Fernandes, 1990) (dotted line in Fig. 1) with locations of analyzed samples; ${ }^{207} \mathrm{~Pb} /{ }^{206} \mathrm{~Pb}$ zircon ages from metasedimentary rocks are displayed in the map (from Gruber et al., 2011); B: Detritic zircon distribution (207 Pb/206 Pb ages) of Porongos metasedimentary sequences (from Gruber et al., 2011). All analysis displayed are less than $10 \%$ discordant, with age uncertainties smaller than $20 \%(2 \sigma)$. The age of volcanism is from Porcher et al. (1999) and Saalmann et al. (2010). Analytical methods used in this analysis can be obtained in Simon et al. (2004) and Chemale et al. (2012); C, D: Petrographic features of sample POR 18, showing quartz and plagioclase aggregates with interlayered mica (Polarized light); B, D: Cross-polars photograph for the same sample, displaying interlobed contact between quartz grains.

In the southern continuation (Uruguay), the DFB is represented by its eastern domain. Following recent works, the DFB is considered separated from RdLP by the Sierra Balena Shear Zone (SBSZ) to the west, which overprints the Porto Alegre Suture in Brazil. The age of low temperature of latest stage of deformation in the SBSZ was dated by ${ }^{40} \mathrm{Ar}-{ }^{39} \mathrm{Ar}$ at $580-550 \mathrm{Ma}$ (Oyhantçabal et al., 2010). The eastern domain's oldest lithodemic units are represented in the Cerro Olivo Complex (Gross et al., 2009), intruded by the ca. $800 \mathrm{Ma}$ Cerro Bori orthogneisses, interpreted as a Neoproterozoic continental volcanic arc (Lenz et al., 2011).

The PMC outcrops in a NE-SW trending terrain $150 \mathrm{~km}$ long and 10 to $15 \mathrm{~km}$ wide, with minor segments of its basement, the Encantadas Complex, tectonically interleaved in the west portion. The PMC is composed mainly of metasedimentary and metavolcanic sequences intruded by granitoid sheets. However, the original stratigraphy is poorly preserved due to superimposed deformation and metamorphism including high strain zones Jost and Bitencourt, 1980; Fernandes et al., 1992; Fernandes et al., 1993).

The lithodemic units comprising DFB are affected by syn-to-post accretionary strain of what is interpreted as successive subductions and collisions (Fernandes et al., 1995a; Frantz et al., 1999) or the collision of a microplate or terrain on the reworked margin (Tandilla belt) of RdLP (Chemale, 2000; Rapela et al., 2011; Chemale et al., 2012). This same strain is responsible, at least in part, for the obliteration of the original framework of the PMC metasedimentary sequences and intrusive rocks. Lack of primary contacts, bedding and way-up criteria also cause 
stratigraphic relationship to be a problematic issue. The best constraining regarding the PMC paleobasin fill is suggested by lack of Neoproterozoic zircon detrital grains in the quartzites of Santana Formation, with a maximum depositional age for these quartzites of ca. 1.7 Ga (Pertille et al., 2015a).

The outcropping pattern of the PMC is controlled by regional NE-SW antiforms, that folded the main ductile fabric, and by late NE-SW strike slip and normal faults. In the PMC central-west portion, the metasedimentary lithodemic units outcropping are exposed along the limbs of the Santana da Boa Vista Antiform (Fig. 2A). Two metasedimentary units are classified accordingly to having an autochthone and para- autochthone origin and named as Arroio Areião schists and the Cerro Cambará schists, respectively (Jost and Bitencourt, 1980). These units are interlayered by mylonitic granitoids and quartz mylonite lenses. This antiform structure continues to the south, with the same conditions of tectonic imbrication (Porcher, 1990) in the Serra do Godinho Antiform, where metandesitic rocks are observed in the sequence (Chemale, 2000). Basement rocks (mainly high-grade gneisses and amphibolites of the Encantadas Complex) exposed in these antiforms cores are in tectonic contact with PMC rocks by folded shear zones with top to NE-SW stretching lineation and top to NE cinematic indicators (Porcher and Fernandes, 1990). To the central-north of this structure is the Serra dos Pedrosas Antiform, whose rocks comprise metapelites and metavolcanics from the Cerro Cambará, Rincão do Maranhão and Cerro do Facão schists. These display a higher degree of metamorphism with P-T conditions up to amphibolite facies. The timing of peak of progressive metamorphism was estimated with the mylonitic fabric that reworked the progressive metamorphic assemblage was dated between $507 \pm 38$ to $524 \pm 17$ in mylonitic schists in the western area of PMC (Lenz, 2006).

Schists from both Arroio Areião and Cerro Cambará have almost the same mineralogy and textures, with S2 foliation and main mineralogy of chlorite \pm muscovite \pm biotite and quartz. Provenance U-Pb zircon data indicates prevalence of sources of ca. 2.2 - 2.0 Ga (Fig. 2B), with minor Gaussian peaks of 1.6, 1.2 and 1.0 Ga (Basei et al., 2011; Gruber et al., 2011; Pertille et al., 2015a; Pertille et al., 2015b). In the northwest of PMC, serpentinites interpreted as being of ophiolite signature occur in the Capané Antiform, associated with basic to acidic metavolcanic rocks, alkaline orthogneiss and metasedimentary rocks ranging from metaconglomerates to pelitic schists (Marques et al., 2003; Gollmann et al., 2008). The meta-ultramafic lithodemic unit is interpreted as a mélange tectonically emplaced in the volcanic and sedimentary rocks, which is interpreted as a subduction of oceanic crust (Marques et al., 1998a, Marques et al., 1998b). Ar-Ar ages obtained from micas in the Capané schists displayed ages of ca. $600 \mathrm{Ma}$, thus indicating a possible minimum age deposition to these schists sequences (Porcher et al., 2010).

The geochronological data and geological interpretations presented in this section are summarized in Figure 3.

\section{Material and methods}

\subsection{Samples}

Fourteen samples were collected in the western, eastern and southeastern limbs of the Santana da Boa Vista and Cerro do Godinho Antiforms. Sample location is shown in Figure 2A. Samples consist of metapelites, mainly chloritemuscovite schists (POR13, POR12, POR06 and POR04 from the eastern side of the Santana Antiform; and RIP03, RIP05, RIP06, RIP07 and RIP09 from the western and southern areas of the same antiform, as well as from one area to the north of Cerro do Godinho Antiform), Chlorite-muscovite phyllite from south of Cerro do Godinho Antiform (RIP 15) and quartz mylonites (RIP11) from the eastern limb of the same antiform. Two (quartz)muscovite-chlorite schists were collected from the eastern side of Santana Antiform (POR11 and POR06). Also from the eastern Santana Antiform, a fine-grained metarenite was collected (POR18). Petrography depicts feldspar-quartz and muscovite-chlorite in an oriented matrix. Deformed plagioclase are presented with grain size $<0.2 \mathrm{~mm}$, and smaller grains of chlorite and micas in millimeter lenses, with plagioclase porphyroclasts in a biotite-quartz-feldspatic lepidoblastic matrix (Fig. 2C, D), also displaying iron oxides.

Other metapelitic sample display quartz lenses of millimeter to centimeter thickness in schist samples of the eastern areas (POR11), with quartz and recrystallized plagioclase occurring in centimetric to millimetric porphyroclasts (see Supplementary materials 1-3 for summary on sample descriptions). Quartz boudins are common. Matrix generally displays granoblastic quartz with folded pervasive micas. Some quartz lenses occur parallel to folding, whereas some occur at high angle $\left(90^{\circ}\right)$. Some mica displays augen features with quartz grains. Muscovite displays bookshelves with granoblastic quartz. Parasitic folds occur marked by asymmetric foliation and 
crenulation. In some samples (POR 04, 06, 11) occur phlogopite in intrafolial fold within the lepidoblastic matrix. The lepidoblastic matrix is composed of thin lenses of
$<1 \mathrm{~mm}$ biotite, interlayered between polygonal granoblastic quartz and plagioclase grains varying from 0.2 to $0.6 \mathrm{~mm}$. Table 1 presents a summary of analyzed samples.

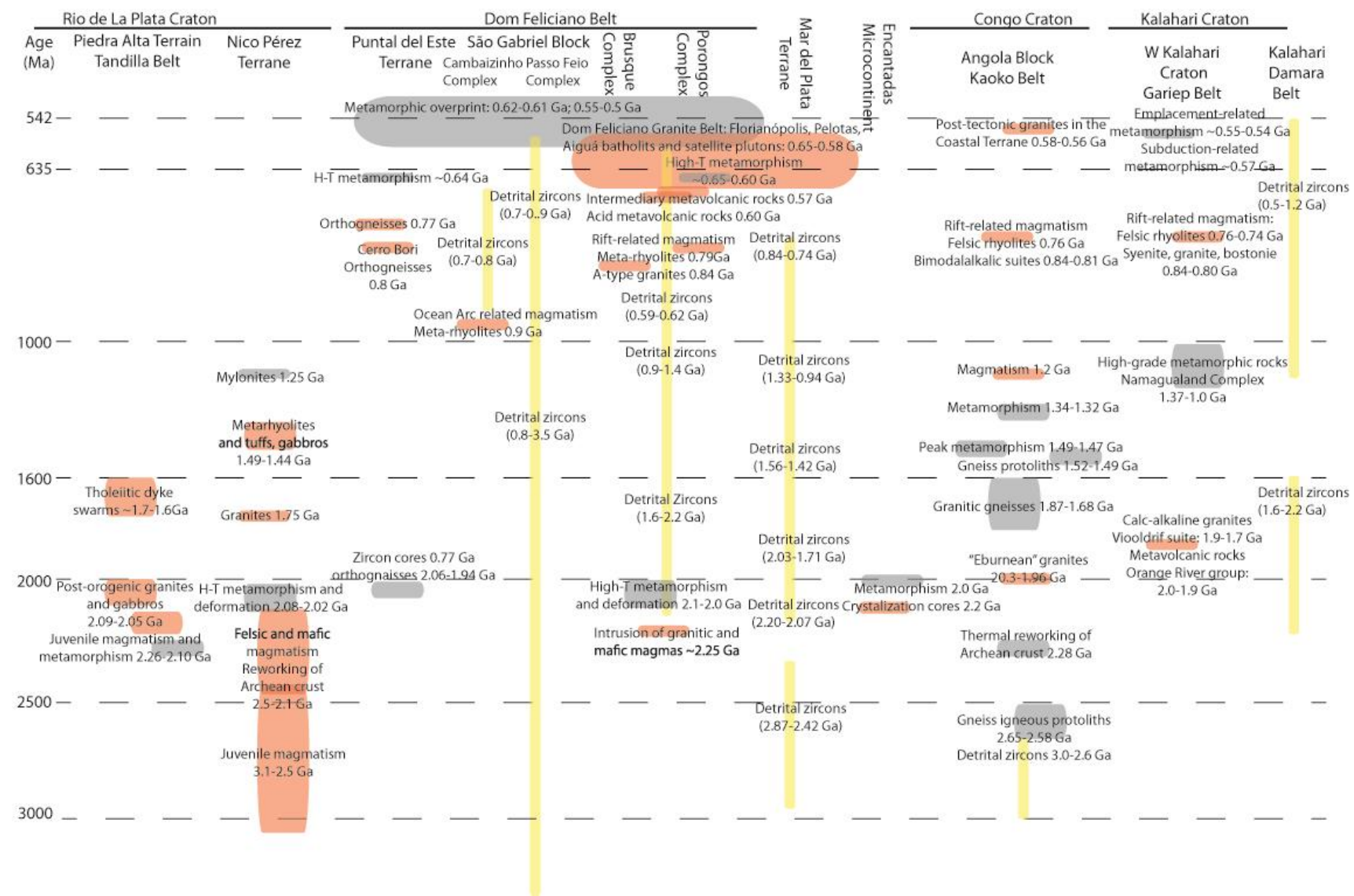

Fig. 3. Summarized comparison of zircon magmatic and metamorphic ages from the main cratons and mobile belts associated with DFB and PMC. Modified from Rapella et al. (2011), with added data from Lenz et al. (2011), Lenz et al. (2012), Lena et al. (2014), Lopes et al. (2015), Foster et al. (2015) and references therein.

\subsection{Whole-rock geochemistry and isotopic analytical techniques}

All the isotopic analyses discussed here were carried out at the Isotope Geology Laboratory of Rio Grande do Sul Federal University (UFRGS).

Whole-rock major and minor element geochemistry analyses were carried out in samples POR 04, 06, 11, 12, 13 and 18 using a Rigaku RIX 2000 X Ray Fluorescence (XRF) at the Geochemistry Laboratory of UFRGS. All analyzed samples displayed high loss on ignition values, being indicative that these samples were affected by alteration. More details on the methodology can be obtained in Brown et al. (1973).
For Sm-Nd analyses (samples POR04, POR06, POR11, POR12 POR13, POR18, RIP03, RIP05, RIP06, RIP07, RIP09, RIP11, RIP13 and RIP15), sample dissolution was carried out in Teflon Savillex beakers, with $\mathrm{Sm}$ and $\mathrm{Nd}$ extraction from about $0.15 \mathrm{~g}$ whole-rock powders from each sample. Conventional chromatography cation-exchange methods were used, with dissolution in $\mathrm{HNO}_{3}$ and $\mathrm{HF}$ in Savillex ${ }^{\circledR}$ vials, with the addition of mixed ${ }^{149} \mathrm{Sm} /{ }^{150} \mathrm{Nd}$ tracer. REEs were separated in cationic exchange AG50W-X8 resin columns (200 to $400 \mathrm{mesh}$ ), and Sm was separated from $\mathrm{Nd}$ with anionic exchange LN-B50-A resin columns (100 to $200 \mu \mathrm{m}$ ). The analyses were carried out using a Finnigan Neptune ICP-MS. 
Uncertainties on $\mathrm{Sm} / \mathrm{Nd}$ and ${ }^{143} \mathrm{Nd} /{ }^{144} \mathrm{Nd}$ ratios are considered better than $\pm 0.1 \%(1 \sigma)$ and $\pm 0.00001(1 \sigma)$, respectively, based on repeated analysis of BHVO-1 standard. ${ }^{143} \mathrm{Nd} /{ }^{144} \mathrm{Nd}$ was normalized to ${ }^{146} \mathrm{Nd} /{ }^{144} \mathrm{Nd}$ ratio of 0.7219. The raw data were reduced using Excel macros made in house. Details on sample dissolution and analysis parameters can be found in Gioia and Pimentel (2000). TDM values were calculated using DePaolo (1981) model.

Tab. 1. Summary of samples; samples marked with $\left(^{*}\right)$ means analysis published in Gruber et al (2011). ESA - East of Santana da Boa Vista Antiform; WSA - West of Santana da Boa Vista Antiform; ECG - East of Cerro do Godinho Antiform; SDP - Serra dos Pedrosas Antiform.

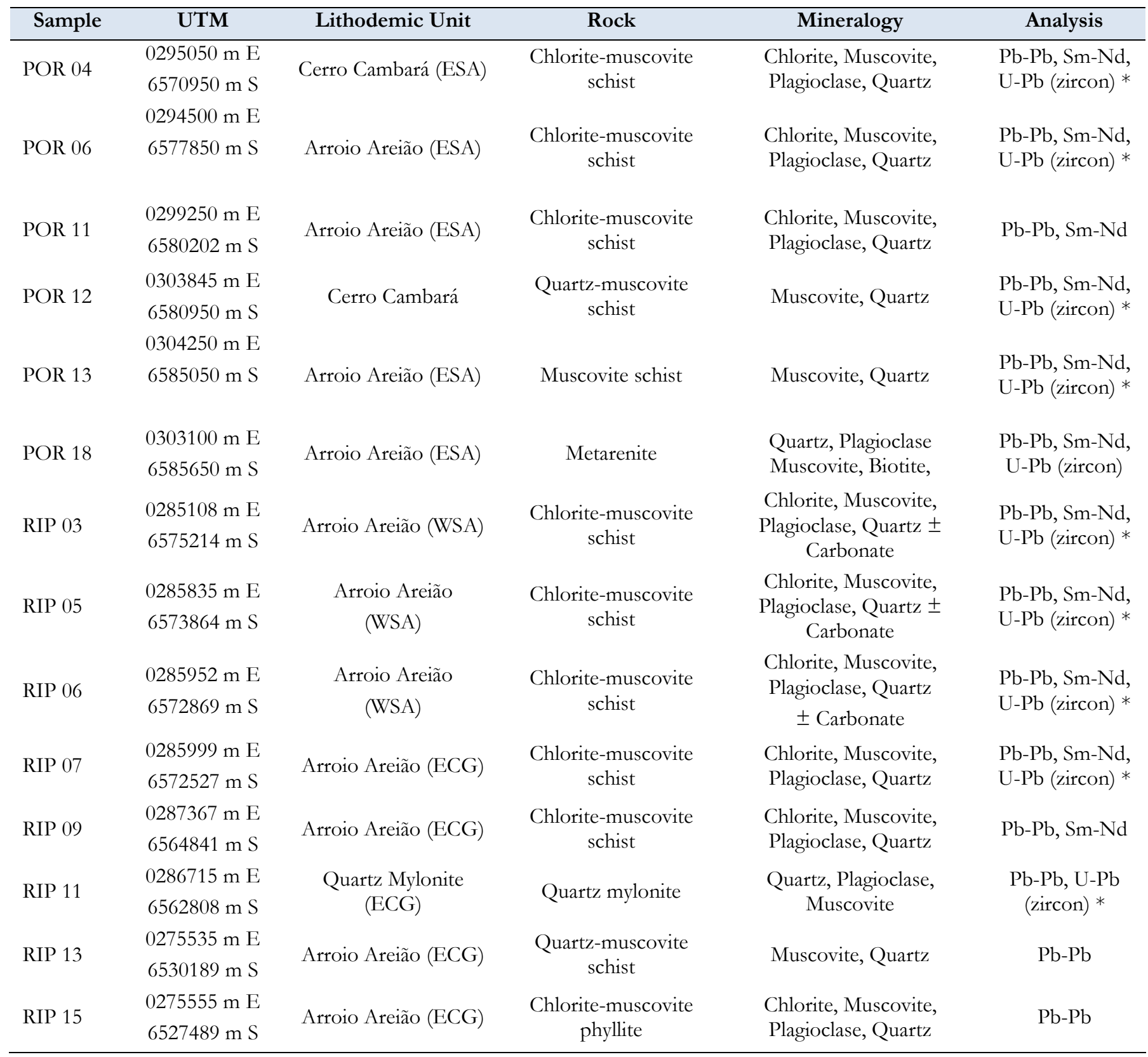


$\mathrm{Pb}-\mathrm{Pb}$ analyses (samples POR04, POR06, POR11, POR12 POR13, POR18, RIP03, RIP05, RIP06, RIP07, RIP09, RIP11, RIP13 and RIP15) were carried out with the same sample dissolution, and were analyzed in Finnigan Neptune ICPMS. Uncertainties on ${ }^{207} \mathrm{~Pb} /{ }^{206} \mathrm{~Pb}$ are considered better than $\pm 0.1 \%(1 \sigma)$ and $\pm 0.001(1 \sigma)$, respectively, based on repeated analyses of BHVO-1 standard. Details in sample dissolution and analysis parameters can be found at Abre et al. (2012).

\subsection{Zircon U-Pb geochronology}

Zircon grains were mounted in epoxy mounts. Images of zircons were obtained using an optical microscope as well as a back-scattered electron detector coupled to a JEOL JSM 5800 electron microscope. Zircon grains were dated with laser ablation microprobe (New Wave UP213) coupled to a MC-ICP-MS (ThermoFinnigan-Neptune) at the Isotope Geology Laboratory of UFRGS. Isotope data where acquired using static mode with spot size of $25 \mu \mathrm{m}$, with frequency of $10 \mathrm{~Hz}$ and intensity of $\sim 4 \mathrm{~J} / \mathrm{cm}^{2}$. Analyses were made in 40 cycles of $1 \mathrm{~s}$, with laser-induced elemental fractionation and instrumental mass discrimination corrected by GJ-1 (standard zircon) with the measurement of two GJ-1 analyses to every ten sample zircon spots. Details on configuration and other analysis parameters can be found in Chemale et al. (2012). The external error was calculated after propagation of the error of the GJ-1 mean and the individual sample zircon. Data were reduced using in-house programs developed at the Isotope Geology Laboratory of UFRGS. Age calculations were carried out with ISOPLOT 3.0 (Ludwig, 2003).

\section{Results}

\subsection{Whole rock geochemistry}

CIA (Chemical Index of Alteration) values, which indicates influence of original weathering on sediments composition varied from 65.19 to 85.96. Metarenite displayed a value of 77.35 , which is characteristic of middle to highly weathered sediments (Nesbitt and Young, 1982; Taylor and McLennan, 1985). These values could also be representing remobilization, since hydrothermal liquids from metamorphism could lead to alteration of the original composition of these values.

$\mathrm{SiO}_{2}$ and $\mathrm{Al}_{2} \mathrm{O}_{3}$ content indicate sedimentary protoliths with granitic composition compared to granite and mafic standards. Values of $\mathrm{TiO}_{2} / \mathrm{Zr}$ below 0.33 were found in samples POR11, POR12, POR18, indicative of pelitic sources in the original composition. When compared to other chlorite schists, quartzites and phyllites from Capané Antiform, the values found in Santana da Boa Vista Antiform presents a diversity of protolith composition, with the metarenite (POR18) composed of mature sediments (pelitic sources).

\subsection{Sm-Nd isotope geochemistry}

$\varepsilon_{\mathrm{Nd}}(\mathrm{T})$ (Fig. $4 \mathrm{~A}$ ) values were calculated for ca.750 Ma, which can be used as average age of deposition for all PMC metasediments.

Samples from metasedimentary rocks of the Rincão do Maranhão, Cerro Cambará and Cerro do Facão show less variation in $T_{\mathrm{DM}}$ and $\varepsilon_{\mathrm{Nd}}$ values when compared with those from the Arroio Areião sequence. For the Cerro Cambará rocks, $T_{\mathrm{DM}}$ values are of ca. $1.74 \mathrm{Ga}$ in the Santana da Boa Vista Antiform, and range from 1.56 to $1.90 \mathrm{Ga}$ in the Serra dos Pedrosas antiform. Supracrustal rocks from the Serra dos Pedrosas Antiform includes the Rincão do Maranhão schists, which display $T_{\mathrm{DM}}$ values between 1.71 and $1.75 \mathrm{Ga}$, and the Cerro do Facão metasediments, with $T_{\mathrm{DM}}$ values varying from 1.64 to $2.00 \mathrm{Ga}$ (Fig. 4B). Rocks of the Arroio Areião displays a more varied pattern for both model ages and $\varepsilon_{\mathrm{Nd}}$ values, with $T_{\mathrm{DM}}$ varying between 1.40 and $2.58 \mathrm{Ga}$, and $\varepsilon_{\mathrm{Nd}}(\mathrm{T})$ at the age of deposition varying from -11.5 to 0.7 (Fig. 4C).

$\varepsilon_{\mathrm{Nd}}$ values of the Arroio Areião near the eastern flank of the Santana da Boa Vista Antiform suggest mafic sourcerocks, possibly those from northern part of the belt. Variation of $\mathrm{Nd}(\mathrm{ppm})$ vs $\varepsilon_{\mathrm{Nd}}(\mathrm{T})$ suggests mixture between detrital sedimentary and volcanic rocks in the source of the Arroio Areião schists (Fig. 4D). Considering $\mathrm{f}(\mathrm{Sm} / \mathrm{Nd})$, there are at least two end-sources (POR18 - similar to metabasalts from Antiform Capané; and RIP11 - close to negative $\varepsilon_{\mathrm{Nd}}$, Gneisses from Encantadas Complex) and the rest of samples plotting in between these (Fig. 4E).

\subsection{Pb-Pb isotope geochemistry}

Although $\mathrm{Pb}$ is a more mobile element than $\mathrm{Sm}$ and $\mathrm{Nd}$ during secondary processes, comparisons between thorogenic and uranogenic $\mathrm{Pb}$ may be used to help distinguishing between different tracts of sialic crust and, therefore, source rocks of detrital sedimentary rocks (Kay 


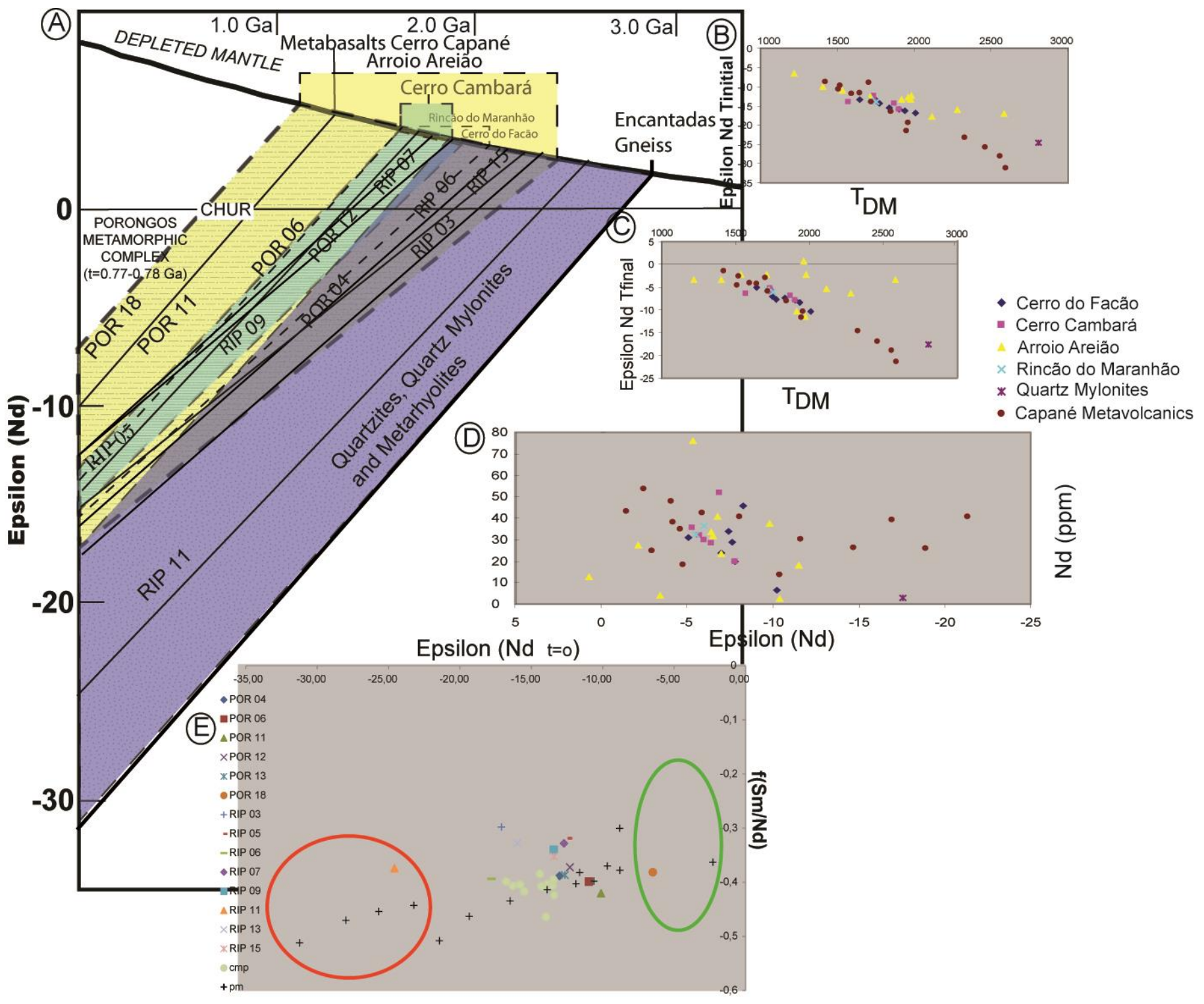

Fig. 4. A: $E N d$ vs. time diagram of the analyzed samples. Metabasalts Arroio Capané data from Gollmann et al. (2008); Encantadas complex from Chemale (2000); B: Plot of the $T_{\mathrm{DM}}$ ages for $E N d(\mathrm{~T}=0)$ for analyzed samples; samples from Arroio Areião metasediments have a stronger dispersion, whereas metasediments from Cerro Cambará, Rincão do Maranhão and Cerro do Facão have $T_{\mathrm{DM}}$ and $\mathcal{E N d}$ less variations; in comparison, metavolcanics of Capané Antiform displays a trend similar to the metasediments of Arroio Areião, with the exception of sample POR 18; C: Variation of $T_{\mathrm{DM}}$ ages for $\varepsilon N d(\mathrm{~T}=750 \mathrm{Ma})$, with Arroio Areião metasediments showing a broader occurrence of $\varepsilon N d(t)$, with the more juvenile sample being the metarenite sample from east of Santana da Boa Vista Antiform (POR 18); metasediments from other units displays negative $\mathcal{E} N d$ values, with the more negative being sample from quartz mylonite localized at south of Santana da Boa Vista Antiform; D: Diagram of $\mathrm{Nd}$ (ppm) against $\mathcal{E} \mathrm{Nd}(\mathrm{t})$, where Arroio Areião samples displays again large variations; samples from Cerro Cambará and Cerro do Facão displays almost the same quantities of $\mathrm{Nd}$; $\mathrm{E}: \mathrm{f}(\mathrm{Sm} / \mathrm{Nd})$ displaying mixture between two end-members (POR18/ metagabros from Capané Antiform - green circle - and RIP11 /metavolcanics from Capane Antiform - red circle). Rincão do Maranhão and Cerro do Facão data from Lenz (2006); data on metavolcanics of Capané Antiform from Gollmann et al. (2008). 
et al., 1996; Tosdal, 1996; Loewy et al., 2003 Schwartz and Gromet, 2004; Oyhantçabal et al., 2011).

The samples investigated in this work, from both the Arroio Areião and the Cerro Cambará schists, have uranogenic ${ }^{207} \mathrm{~Pb} /{ }^{204} \mathrm{~Pb}$ ratios higher than 15.50 , and ${ }^{206} \mathrm{~Pb} /{ }^{204} \mathrm{~Pb}$ values higher than 18.55 . Samples from Cerro Cambará plot near values for the Kalahari granitoids and Cerro Bori orthogneiss, with values varying from ${ }^{206 \mathrm{~Pb}} /{ }^{204} \mathrm{~Pb}$ of $\mathrm{ca} .19 .0$ and ${ }^{207} \mathrm{~Pb} / 204 \mathrm{~Pb}$ of ca. 15.75. Both thoranogenic and uranogenic values plot above the SandK (Stacey and Kramers, 1975) curve of evolution of crustal rocks, indicating sources that were highly radiogenic compared to average crust.

Regarding the metasedimentary sequences described, they should be useful as an indicator of possible mixtures between strongly different source-areas. Basements like those of Laurentia display ${ }^{206} \mathrm{~Pb} /{ }^{204} \mathrm{~Pb}$ ratios below 19.0, and ${ }^{207} \mathrm{~Pb} / 204 \mathrm{~Pb}$ below 15.5 , whereas these values for both Kalahari and RdLP cratons are substantially higher. The analysis of orthogneisses from Cerro Bori (in the Uruguayan eastern domain of DFB) has provided values comparable to those obtained in granitoids from Fafa, Africa (Lenz et al., 2012).

Samples from Arroio Areião do display a broader pattern, plotting between those values typical of the Kalahari and RdLP cratons (Fig. 5A). Samples RIP 03 and 05 , located west of Santana Antiform, displayed very high radiogenic $\mathrm{Pb}$ content. Thoranogenic values suggests a variation on terrain sources from West and East of Santana da Boa Vista Antiform (Fig. 5B), although these metasediments probably have a common source.
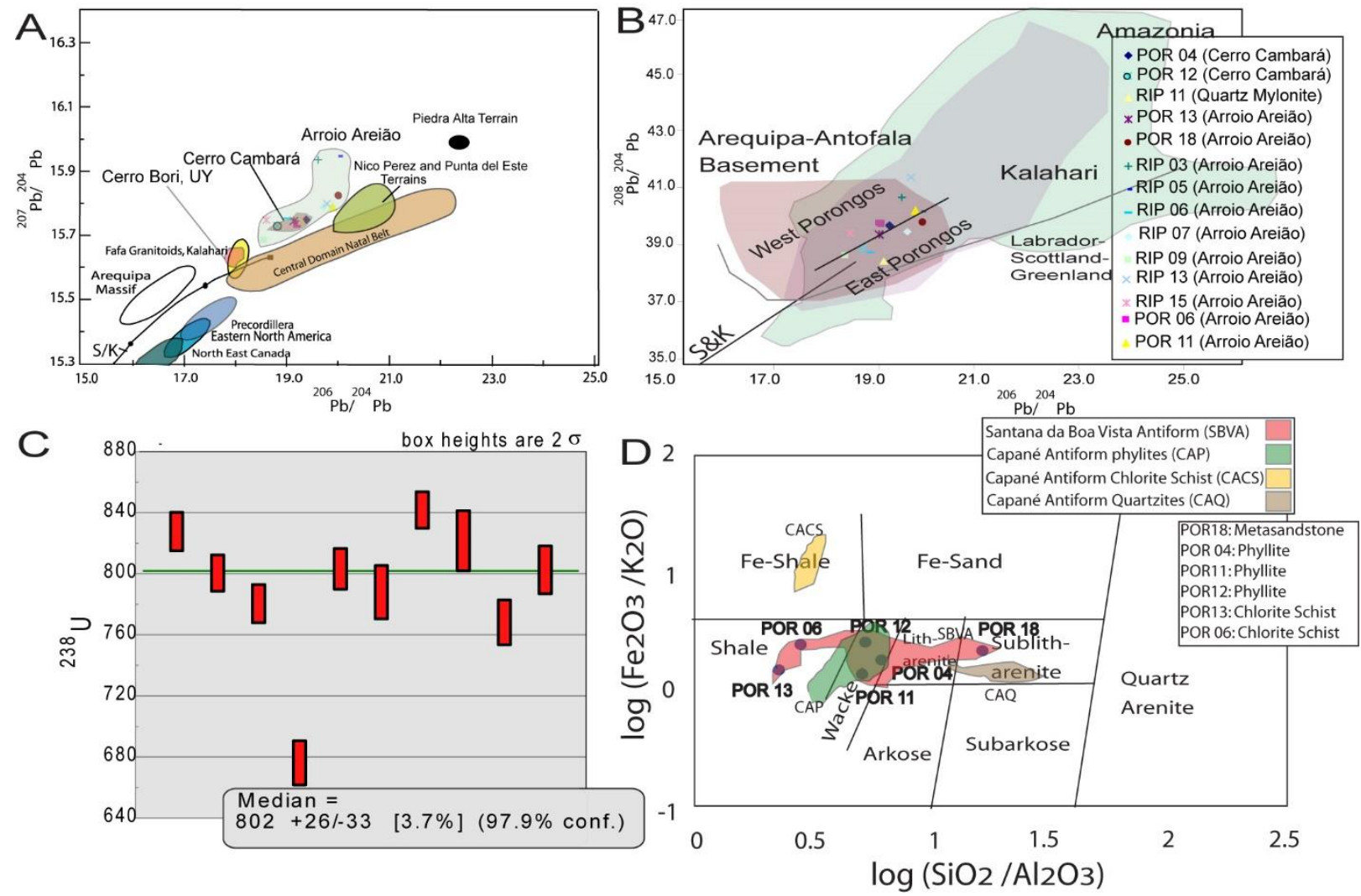

Fig. 5. A: Uranogenic ${ }^{207} \mathrm{~Pb} /{ }^{204} \mathrm{~Pb}$ vs. ${ }^{206} \mathrm{~Pb} /{ }^{204} \mathrm{~Pb}$ diagram displaying large compositional variation for samples from the Arroio Areião sequence, while samples of the Cerro Cambará display values within a narrower range; comparison with possible source cratons shows that there is no participation of sediments with Laurentian affinity (Eastern North America and Canada) and strong resemblance with African and RdLP sources, particularly Nico Perez and Punta del Este terrains (Modified from Oyhantçabal et al., 2011). Data from Cerro Bory presented by Lenz et al. (2012); B: Thoranogenic ${ }^{208} \mathrm{~Pb} /{ }^{204} \mathrm{~Pb}$ vs. ${ }^{206} \mathrm{~Pb} /{ }^{204} \mathrm{~Pb}$, displaying metasediments from east and west of Santana da Boa Vista antiform; C: Median age calculated from zircon ${ }^{238} \mathrm{U} /{ }^{206} \mathrm{~Pb}$ analysis on POR 18; D: Sedimentary rock classification (Herron, 1988), with faded fields indicating data from Petry (2014). 


\subsection{Geochronology}

Aiming to constraint possible depositional age and syn-depositional volcanism in the metasedimentary units, ten zircon grains of the sample POR 18 analyzed were selected to be studied here. The Neoproterozoic nine concordant analyses resulted in ${ }^{207} \mathrm{~Pb} / 206 \mathrm{~Pb}$ ages varying from $765 \pm 19 \mathrm{Ma}$ to $796 \pm 19 \mathrm{Ma}$ (Fig. 6). Samples from schists of the same lithodemic unit have older zircon grains, ranging from $1113 \pm 42 \mathrm{Ma}$ to $2195 \pm 31$ Ma (Gruber et al., 2011). The prevalence of ages clustered between 821 and $710 \mathrm{Ma}$, with a median age calculated with Isoplot (Ludwig, 2003) of $802+26 /-33$ Ma (Fig. 5C).

\section{Discussion}

\subsection{Source areas}

Since practically all PMC samples analyzed in others works displayed detrital ages of ca. 2.2 and $2.0 \mathrm{Ga}$, Encantadas Complex, with magmatic crystallization zircon ages of $2.2 \mathrm{Ga}$; metamorphism of 2.0-1.8 Ga (Chemale, 2000; Phillip et al., 2008) should have acted as a main source to all formations in the PMC. The Encantadas Complex displays negative $\varepsilon N d$ values (Chemale, 2000), reaffirming its contribution to the PMC metasediments displayed in Figure 4A.

Similar detrital zircon ages (see Fig. 2B) occur in both the Arroio Areião and Cerro Cambará schists, although the younger ages obtained are from the first lithodemic unit (Gruber et al., 2011). High ${ }^{207} \mathrm{~Pb} / 204 \mathrm{~Pb}$ vs ${ }^{206} \mathrm{~Pb} / 204 \mathrm{~Pb}$ values (15.94-15.68 and 20.01-18.55) obtained in Arroio Areião schists indicate mixture between African sources with Elzeverian zircon ages with reworked RdLP sediments. Mesoproterozoic detrital zircon ages from Cerro Cambará displays the same U-Pb ages compared to Arroio Areião, although the $\varepsilon_{\mathrm{Nd}}(0)$ value of -13 indicates evolvedcrustal sources. The Arroio Areião samples displays variable values both in $\varepsilon_{\mathrm{Nd}}$ vs $\mathrm{Nd}(\mathrm{ppm})$ and in $T_{\mathrm{DM}}$ vs. $\varepsilon_{\mathrm{Nd}}(\mathrm{t})$, plotting next to values obtained in metavolcanics of Capané Antiform analyzed by Gollmann et al. (2008) (Fig. 4A). This suggests a tectonic setting where the sediments of Arroio Areião where deposited along volcanic rocks of ca. 800-760 Ma (Porcher et al., 1999; Saalmann et al., 2010; Lenz et al., 2012). The presence of detrital zircon grains with the same ages from that obtained in zircons from metavolcanics rocks dating of ca. $780 \mathrm{Ma}$ corroborates to the suggestion of Arroio Areião unit being a mixture of the older detritus, probably composed of quartz milonytes, with younger and juvenile volcanic local sources.

Metabasalts with OIB-MORB geochemistry from Capané antiform displays slightly negative $\varepsilon_{\mathrm{Nd}}$ (Gollmann et al., 2008), and $T_{\mathrm{DM}}$ ages varying from Paleo to Mesoproterozoic, compatible with those of POR18 sample $\left(\varepsilon_{\mathrm{Nd}}-0.6\right.$ and $\left.T_{\mathrm{DM}} 1.21 \mathrm{Ga}\right)$ (Fig. $\left.4 \mathrm{~A}\right)$, which could argue favorable to the hypothesis of the less negative $\varepsilon_{\mathrm{Nd}}$ metasediments of PMC having the same source as the material that generated the metabasalts. If they indeed have same source, the OIB-MORB characteristic of these metabasalts could represent consumption of oceanic crust in a collisional setting. In this case, another source could be argued to the Neoproterozoic record, as part of the Dom Feliciano arc (Chemale et al., 2012). These characteristic OIB-MORB metabasalts can argue favorably to an arc or back-arc setting to this PMC section, now localized in the northeastern section of the belt. Comparison between metasediments and metavolcanics from the Capané Antiform (Gollmann et al., 2008) suggests a strong similarity between the metasediment source rocks and Porongos metavolcanics, but volcanic zircon ages obtained in metatuffs from the Capané Antiform displayed younger ages than those obtained in Santana da Boa Vista Antiform, ranging from $601 \pm 2.6$ to $578 \pm 1.6 \mathrm{Ma}$ (Kohlrausch, 2013).

All samples from east and southeast of Santana da Boa Vista Antiform displays $\mathrm{Pb} / \mathrm{Pb}$ values comparable to those of Nico Perez and Punta del Este terrains, with ${ }^{206} \mathrm{~Pb} /{ }^{204} \mathrm{~Pb}$ varying from ca. 21 to ca.18, and ${ }^{207} \mathrm{~Pb} / 204 \mathrm{~Pb}$ from ca.15.7 to ca.15.9 (see Fig. 5A), nearer to the La Plata craton. Since there is less indicators of RdLP sources for Mesoproterozoic detrital zircon ages, and evidence for an agglutination of Braziliano terrains of Dom Feliciano and Nico Perez only in Neoproterozoic (Oyhantçabal et al., 2011), the sources with ages younger than $0.9 \mathrm{Ga}$ are probably derived from RdLP craton, principally the accreted terrains of Nico Perez and Mar del Plata, explained by the mixture between RdLP and African sources obtained in the metasediments of the PMC.

\subsection{Syn-volcanic deposition (ca. $780 \mathrm{Ma}$ )}

The zircons dated in sample POR-18 could be implying a syn-depositional volcanic event. Following CongoKalahari rifting phase (780-740 Ma), Adamastor Ocean begins consumption on its active margins until final stages 


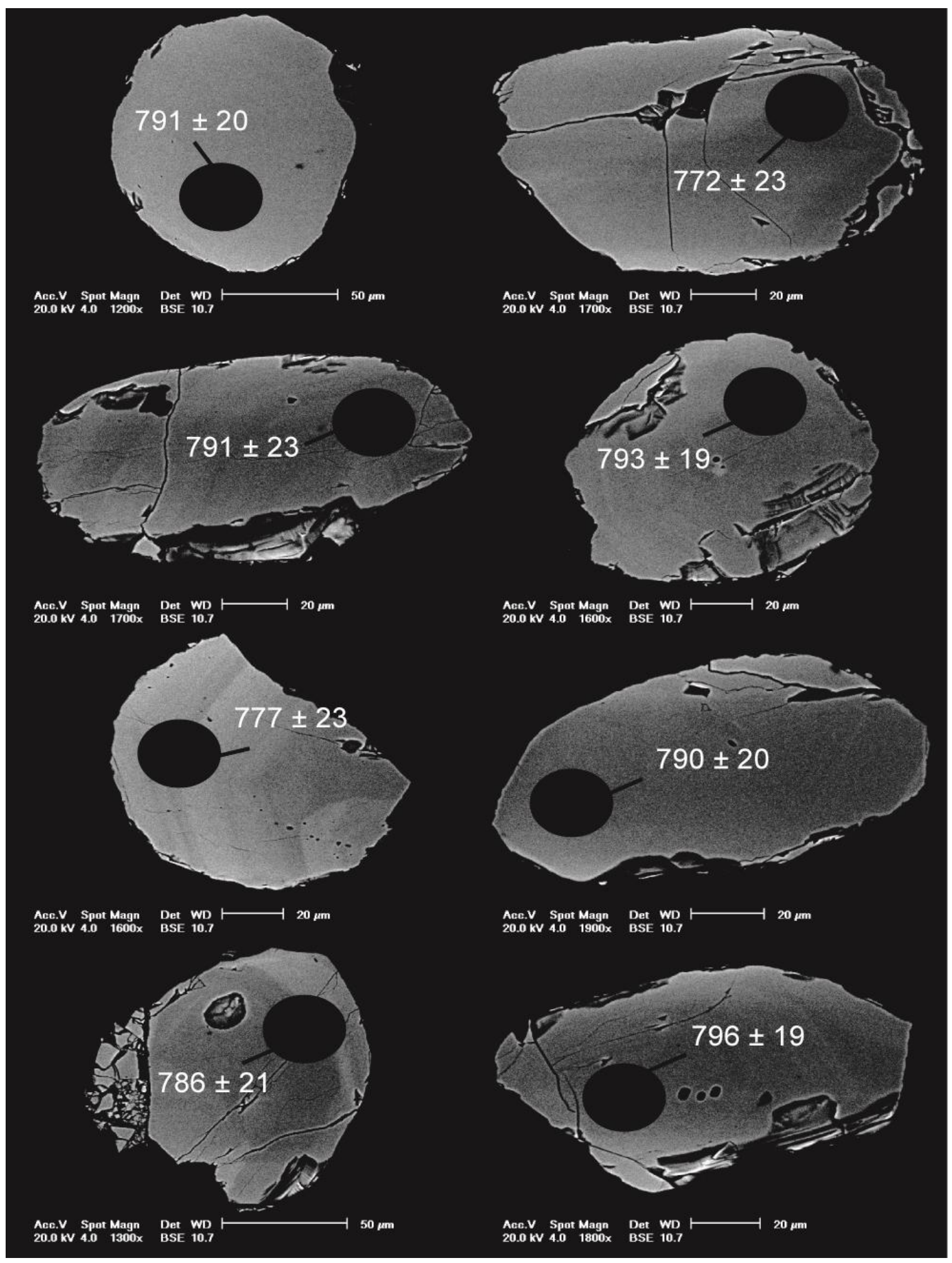

Fig. 6. BSE images from analyzed zircon grains presenting less than $10 \%$ discordance, ${ }^{207} \mathrm{~Pb} /{ }^{206} \mathrm{~Pb}$ ages are displayed in the spot positions. 
of Adamastor ocean basin closure (ca. $550 \mathrm{Ma}$, Gray et al., 2006). The event of rifting could be marking here the initial development of an active margin at RdLP craton (Basei et al., 2011).

\subsection{Tectonic setting and evolution}

Paleoproterozoic (ca. 2.2 - $2.0 \mathrm{Ga}$ ) sources from basement, like Encantadas Complex (Fig. 3), hardly serves to constraining maximum and minimum timing of deposition of PMC metasedimentary rocks. The age of the agglutination of Encantadas Complex in the RdLP margin can be estimated between two models. One possibility is the age of deposition of PMC supracrustal rocks and the pos-depositional metamorphic fabric dated as a minimum age of Braziliano tectonic transcurrency of $540 \mathrm{Ma}$. The other possibility is a maximum age of subduction of an oceanic plate in a continental crust and subsequent metamorphism in the Paleoproterozoic (Phillip et al., 2008), with this continental volcanic arc opening the paleobasin after this tectonic event. Deposition of PMC quartzite units in the Santana da Boa Vista Antiform (Pertille et al., 2015a) occurred after developing of this margin (ca. 1.7 Ga). In the other hand, considering the data presented here, we can assume that the analyzed metarenite of PMC registers the continental arc volcanism of ca. $800 \mathrm{Ma}$. The deposition of this system should be younger than Paleo to Mesoproterozoic but older than the Braziliano transcurrency. Thus, the PMC paleobasin opened at ca. 0.9 $\mathrm{Ga}$, in a passive margin or rifting system in the Adamastor Ocean. The central section of DFB does have a rifting system active in the Tonian-Cryogenian that could corroborate this model (ca. $840 \mathrm{Ma}$, Basei et al., 2008), although these ages are not registered in the southern DFB.

There is a low input of $\mathrm{U}-\mathrm{Pb}$ provenance ages from 765 to $690 \mathrm{Ma}$ in the detrital record for schist samples to the north and south of the Santana da Boa Vista Antiform (see histogram data presented in Gruber et al., 2011; Basei et al., 2011; Pertille et al., 2015a, 2015b, for more details), suggesting a non-deposition time span, or absence of source-areas of this age, and therefore can be interpreted as a change in tectonic setting. Since usually collisional settings produces low volumes of magma (Hawkesworth et al., 2010), the final setting of Porongos paleobasin can be considered as a continental orogenic accretionary setting, considering the very low input of ca. $700 \mathrm{Ma}$ or younger detrital zircons (see Hartmann et al., 2004; Gruber et al., 2011; Basei et al., 2011; Pertille et al., 2015a, 2015b for more details in $\mathrm{U}-\mathrm{Pb}$ provenance aspects of $\mathrm{PMC}$ ). Sm-Nd geochemistry corroborates the hypothesis of a continental arc, since there predominance of negative to highlynegative $\varepsilon_{\mathrm{Nd}}$ in the analyzed samples.

These ca. 820-760 Ma ages are about the same ages verified in metavolcanics from Santana da Boa Vista Antiform (Porcher et al., 1999; Saalmann et al., 2010), in metarenites from Punta Mogotes borehole (Rapela et al., 2011) and in the Cerro Bori orthogneisses, interpreted as a continental volcanic arc (Lenz et al., 2012), which suggests a link between the U-Pb geochronological data obtained here and the evolution of continental margin in the RdLP craton. It's important to note that there is registry of ca. $780 \mathrm{Ma}$ in SHRIMP U-Pb zircon ages obtained in a $3 \mathrm{~m}$ sized tonalitic xenolith (Silva et al., 1997a), with graniticgneisses intruded in metasedimentary sequences of Pinheiro Machado Complex dated at ca. $631 \mathrm{Ma}$, interpreted as high grade metamorphism (Silva et al., 1997b). This tonalitic xenolith could be remnant of a ca. 800-780 Ma continental arc in the vicinity of PMC paleobasin.

Varied profundity of some portions of the paleobasin inducted by differences in size of local basement also could have influence on the metamorphism occurring at some portions of PMC while others remain as an open basin in the Ediacaran (ca. $0.57 \mathrm{Ga}$ ), thus explaining some of the zircons displaying ca. 620-580 (Basei et al., 2008; Gruber et al., 2011; Pertille et al., 2015b). These detrital zircon ages are younger than some metamorphic events dated in the PMC, with ages obtained by Rb-Sr and Ar-Ar methods of ca. $600 \mathrm{Ma}$ (Lenz, 2006; Porcher et al., 2010). In the case of a continental-collision tectonic setting, we should expect some degree of variability. Nonetheless, the geologic framework of the Complex does not permit a classic solution to the question of what was the environmental setting at time of deposition.

\section{Conclusions}

The metasediments from PMC presents remarkable geochemical and geochronological characteristics. Arroio Areião and Cerro Cambará schists in the east of Santana da Boa Vista Antiform displays less crustal-contaminated $\mathcal{E N d}$ factor (Arroio Areião) and $\mathrm{Pb}-\mathrm{Pb}$ analysis trending to those obtained in rocks of Rio de La Plata craton. They are distinct from metasediments of Arroio Areião (Southwest of Santana da Boa Vista Antiform), Cerro Cambará (in East and Southeast of Santana da Boa Vista Antiform), Rincão do Maranhão and Cerro do Facão, with negative $\varepsilon_{\mathrm{Nd}}$ and highly evolved crust in the sources. The quartz mylonites at 
Santana da Boa Vista Antiform were originally sediments with very negative $\varepsilon_{\mathrm{Nd}}$, and Paleoproterozoic to Archean $\mathrm{Nd}$ model ages.

PMC paleobasin should be localized somewhere between Kalahari, Congo and RdLP cratons, but $\mathrm{Pb}-\mathrm{Pb}$ geochemistry suggests that RdLP was not a main sourcearea in the Mesoproterozoic. More detailed studies in this aspect should provide a better understanding of the boundaries of RdLP craton with DFB.

The PMC tectonic depositional setting of the Santana da Boa Vista Antiform schists (between ca. $780 \mathrm{Ma}$ and ca. $590 \mathrm{Ma}$, with maximum depositional age of ca. $570 \mathrm{Ma}$ ) evolves from a passive margin, probably related to the rifting system of Adamastor Ocean, into an accretionary margin basin, ending with the consumption of Adamastor ocean plate and continental collision between accreted terrains of Kalahari, Congo and RdLP cratons. The clastic mature lithodemic units (metarenite) were deposited at the same time as the volcanic rocks dated of ca. $780-800 \mathrm{Ma}$, thus indicating syn-depositional volcanism acting on the vicinity of PMC paleobasin. The same age interval (ca. 780$800 \mathrm{Ma}$ ) is registered in other sections of DFB (Porcher et al., 1999; Saalmann et al., 2010; Rapela et al., 2011; Lenz et al., 2012; Pertille et al., 2015b), and were interpreted as the result of a continental volcanic arc (Lenz et al., 2012). Detrital record (from PMC and Punta Mogotes fm.) display concordance with those volcanic sources, indicating another evidence for the ca. 780-800 Ma continental arc acting during the pre-Gondwana amalgamation registered in the DFB.

\section{Acknowledgments}

We would like to thank Agência Nacional do Petróleo, Gás Natural e Biocombustíveis (ANP), Financiadora de Estudos e Projetos (FINEP) and Ministério da Ciência e Tecnologia (MCT), (PRH-ANP/MCT), Petrobras PRH-PB215 for studentship (first author) and LGI-UFRGS staff for providing analysis and technical support. We also like to thanks Prof. Dr. Márcio Martins Pimentel (UnB), Profa. Dra. Márcia Elisa Boscato Gomes (UFRGS), Dra. Andréia Oliveira Monteiro da Silva Gross (CPRM), Prof. Dr. Enrique Carlos Masquelin (UdeLar) for helping with an early draft of the manuscript, as well as the editor and anonymous reviewers from the Journal of Sedimentary Environments.

\section{References}

Abre, P., Cingolani, C.A., Cairncross, B., Chemale Jr., F. 2012. Siliciclastic Ordovician to Silurian units of the Argentine Precordillera: Constraints on provenance and tectonic setting in the proto-Andean margin of Gondwana. Journal of South American Earth Sciences 40, 1-22.

Almeida, F.F.M., Hasui, Y., Brito Neves, B.B., Fuck, R.A. 1981. Brazilian Structural Provinces: An introduction. Earth Science Reviews 17, 1-29.

Basei, M. A. S., Frimmel, H. E., Nutman, A. P., Preciozzi, F. 2008. West Gonduana amalgamation based on detrital zircon ages from Neoproterozoic Ribeira and Dom Feliciano belts of South America and comparison with coeval sequences from SW Africa. Geological Society, London, Special Publications 294, 239-256.

Basei, M.A.S., Campos Neto, M.C., Castro, N.A., Nutman, A.P., Wemmer, K., Yamamoto, M.T., Hueck, M., Osako, L., Siga, O., Passarelli, C.R. 2011. Tectonic evolution of the Brusque Group, Dom Feliciano belt, Santa Catarina, Southern Brazil. Journal of South American Earth Sciences, 32, 24-350.

Borba, A.W., Mizusaki, A.M.P., Silva, D.R.A., Koester, E., Noronha, F.L., Casagrande, J. 2006. Provenance of the Neoproterozoic Maricá Formation (Sul-rio-grandense Shield, Southern Brazil): Petrographic and $\mathrm{Sm}-\mathrm{Nd}$ isotopic constraints. Gondwana Research 9, 464-474.

Brown, G.C., Hughes, D.J., Esson, J. 1973. New RFX data retrieval techniques and their application to U.S.G.S. standard rocks. Chemical Geology 11, 223-229.

Chemale, F. 2000. Evolução Geológica do Escudo Sul-riograndense. In: Holz, M.; De Ros, L. F. (eds.). Geologia do Rio Grande do Sul. Porto Alegre, CIGO/UFRGS, p. 13-52.

Chemale, F., Mallmann, G., Bitencourt, M.F., Kawashita, K. 2012. Time constraints on magmatism along the Major Gercino Shear Zone, southern Brazil: Implications for West Gondwana reconstruction. Gondwana Research 22, 184-199.

DePaolo, D.J. 1981. A neodymium and strontium isotopic study of the Mesozoic calc-alkaline granitic batholiths of the Sierra Nevada and Peninsular Ranges. California Journal of Geophysical Research 86, 10470-10488.

Fernandes, L.A.D., Tommasi, A., Porcher, C.C. 1992. Deformation patterns in the southern Brazilian branch of the Dom Feliciano belt: A reappraisal. Journal of South American Earth Sciences 5, 77-96.

Fernandes, L.A.D., Tommasi, A., Vauchez, A., Porcher, C.C., Menegat, R., Koester, E. 1993. Zona de Cisalhamento Transcorrente Dorsal do Cangulu: caracterização e importância na compartimentação tectônica do Cinturão Dom Feliciano. Revista Brasileira de Geociências 23, 224-233.

Fernandes L.A.D., Menegat R., Costa A.F.U., Koester E., Kramer G., Tommasi A., Porcher, C.C., Ramgrab G.E., Camozzato E. 1995a. Evolução tectônica do Cinturão Dom Feliciano no Escudo Sul-rio-grandense: Parte I - uma contribuição a partir do registro geológico. Revista Brasileira de Geociências 25, 351 374.

Fernandes L.A.D., Menegat R., Costa A.F.U., Koester E., Kramer G., Tommasi A., Porcher, C.C., Ramgrab G.E., Camozzato E. 1995b. Evolução Tectônica do Cinturão Dom Feliciano no Escudo Sul-rio-grandense: Parte II- Uma Contribuição a partir do registro geofísico. Revista Brasileira de Geociências 25, 375384. 
Foster, D.A., Goscombe, B.D., Newstead, B., Mapani, B., Mueller, P.A., Gregory, L.C., Muvangua, E. 2015. U-Pb age and $\mathrm{Lu}-\mathrm{Hf}$ isotopic data of detrital zircons from the Neoproterozoic Damara Sequence: Implications for Congo and Kalahari before Gondwana. Gondwana Research 28, 179-190. doi: 10.1016/j.gr.2014.04.011

Fragoso-César, A. R. S. 1991. Tectônica de Placas no Ciclo Brasiliano: As Orogenias dos Cinturões Dom Feliciano e Ribeira no Rio Grande do Sul. Tese de Doutorado, USP, São Paulo. 367 p.

Frantz J.C., Botelho N.F., Pimentel M.M., Potrel A., Koester E., Teixeira R.S. 1999. Relações isotópicas Rb-Sr e Sm-Nd e idades do magmatismo granítico brasiliano da região leste do Cinturão Dom Feliciano no Rio Grande do Sul: evidências de retrabalhamento de crosta continental paleoproterozóica. Revista Brasileira de Geociências 29, 227-232.

Gioia, S.M.C.L., Pimentel, M.M. 2000. The Sm-Nd isotopic method in the Geochronology Laboratory of the University of Brasília. Anais da Academia Brasileira de Ciências 72, 219-245.

Gollmann, K., Marques, J.C., Frantz, J.C., Chemale Jr., F. 2008. Geoquímica e Isotópos de $\mathrm{Nd}$ de Rochas Metavulcânicas da Antiforme Capané, Complexo Metamórfico Porongos, RS. Revista Pesquisas em Geociências, 35, 83-95.

Gray, D.R., Foster, D.A., Goscombe, B., Passchier, C.W., Trouw, R.A.J., 2006. 40Ar/39Ar thermochronology of the Pan-African Damara orogen, Namibia, with implications for tectonothermal and geodynamic evolution. Precambrian Research 150, 49-72.

Gross, A.O.M.S., Droop, G.T.R., Porcher, C.C., Fernandes, L.A.D. 2009. Petrology and thermobarometry of mafic granulites and migmatites from the Chafalote Metamorphic Suite: new insights into the Neoproterozoic P-T evolution of the Uruguayan-Sul- Rio-Grandense Shield. Precambrian Research, 170, 157-174.

Gruber, L., Porcher, C. C., Lenz, C., Fernandes, L.A.D. 2011. Proveniência de metassedimentos das sequências Arroio Areião, Cerro Cambará e Quartzo Milonitos no Complexo Metamórfico Porongos, Santana da Boa Vista, RS. Pesquisas em Geociências, 38, 205-224.

Hartmann, L.A., Santos, J.O.S., McNaughton, N.J., Vasconcellos, M.A.Z., Silva, L.C. 2000. Ion Microprobe (SHRIMP) dates complex granulite from Santa Catarina, southern Brazil. Anais da Academia Brasileira de Ciências, 72, 559-572.

Hartmann, L.A., Phillip, R.P., Liu, D.W., Wang, Y., Santos, J. O., Vasconcellos, M.A.Z. 2004. Paleoproterozoic magmatic provenance of detrital zircon, Porongos Complex quartzites, southern Brazilian Shield. International Geology Review, 46, 127-157.

Hasui, Y., dal Carneiro, C.R., Coimbra, A.M. 1975. The Ribeira folded belt. Revista Brasileira de Geociências 5, 257-266.

Hawkesworth, C., Dhuime, B., Pietranik, A., Cawood, P., Kemp, T., Storey, C. 2010. The Generation and Evolution of the Continental Crust. Journal of the Geological Society, 167, 229248.

Herron M.M. 1988. Geochemical classification of terrigenous sands and shales from core log data. Journal of Sedimentary Petrology 58, 820-829.
Jost, H. 1982. Condições do metamorfismo regional de uma parte da faixa de dobramentos de Tijucas no Rio Grande do Sul-RS. Acta Geologica Leopoldensia 12, 3-32.

Jost, H., Bitencourt, M.F. 1980. Estratigrafia e tectônica de uma fração da faixa de Dobramentos de Tijucas no Rio Grande do Sul. Acta Geologica Leopoldensia 4, 27-60.

Kay, S.M., Orrell, S., Abbruzzi, J.M. 1996. Zircon and whole rock $\mathrm{Nd}-\mathrm{Pb}$ isotopic evidence for a Grenville age and a Laurentian origin for the basement of the Precordillera in Argentina. Journal of Geology 104, 637-648.

Kohlrausch, C.B. 2013. Determinação das idades U-Pb em zircão por LA-ICP-ME nas rochas metavulcânicas da Antiforme Capané, Complexo Metamórfico Porongos. Undergraduate thesis, 61 pp. Universidade Federal do Rio Grande do Sul.

Lena, L., Pimentel, M.M., Phillip, R.P., Armstrong, R., Sato, K., 2014. The evolution of the Neoproterozoic São Gabriel juvenile terrane, southern Brazil based on high spatial resolution $\mathrm{U}-\mathrm{Pb}$ ages and $\delta 18 \mathrm{O}$ data from detrital zircons. Precambrian Research, 247, 126-138. doi: 10.1016/j.precamres.2014.03.010

Lenz, C. 2006. Evolução metamórfica dos metapelitos da antiforme Serra dos Pedrosas: condições e idades do metamorfismo. 111 p. Msc thesis, Universidade Federal do Rio Grande do Sul.

Lenz, C., Fernandes, L.A.D., McNaughton, N.J., Porcher, C.C., Masquelin, H. 2011. U-Pb SHRIMP ages for the Cerro Bori Orthogneisses, Dom Feliciano Belt in Uruguay: Evidences of a $\sim 800 \mathrm{Ma}$ magmatic and $\sim 650 \mathrm{Ma}$ metamorphic events. Precambrian Research 185, 149-163.

Lenz, C.C., Porcher, C.C., Fernandes, L.A.D., Masquelin, H., Koester, E., Conceição, R.V. 2012. Geochemistry of the Neoproterozoic (800-767 Ma) Cerro Bori orthogneisses, Dom Feliciano Belt in Uruguay: tectonic evolution of an ancient continental arc. Mineralogy and Petrology 107, 785-806.

Loewy, S.L., Connely, J.N., Dalziel, I.W.D., Gower, F.C. 2003. Eastern Laurentia in Rodínia: Constraints from whole-rock $\mathrm{Pb}$ and U-Pb geochronology. Tectonophysics 375, 169-197.

Lopes, C.G., Pimentel, M.M., Phillip, R.P., Gruber, L., Armstrong, R., Junges, S. 2015. Provenance of the Passo Feio Complex: Implications for the age of supracrustal rocks of the São Gabriel Arc, southern Brazil. Journal of South American Earth Sciences 58, 9-17.

Ludwig, K.R. 2003. Isoplot 3.0 - A geochronological toolkit for Microsoft Excel. Berkley Geochronology Center, Special Publications No. 4.

Marques J.C., Jost H., Roisenberg A., Frantz J.C. 1998a. Eventos ígneos da Suíte Metamórfica Porongos na área da antiforme Capané, Cachoeira do Sul - RS. Revista Brasileira de Geociências 28, 419-430.

Marques J.C., Jost H., Roisenberg A., Frantz J.C. 1998b. Rochas metassedimentares, geologia estrutural e metamorfismo da Suíte Metamórfica Porongos na área da Antiforme Capané, Cachoeira do Sul - RS. Revista Brasileira de Geociências 28, 467-472.

Marques, J.C., Roinsenberg, A., Jost, H., Frantz, J.C., Teixeira, R. S., 2003. Geologia e Geoquímica das Rochas Metaultramáficas 
da Antiforme Capané, Suíte Metamórfica Porongos, RS. Revista Brasileira de Geociências 33, 95-107.

Masquelin, H. 2000. A evolução estrutural e metamórfica do Terreno Punta del Este-Sudoeste Uruguaio. Tese de doutorado. Instituto de Geciências - UFRGS, p. 350.

Nesbitt, H.W.M., Young, G.M. 1982. Early Proterozoic climates and plate motions inferred from major element chemistry of lutites. Nature 299, 715-717.

Oyhantçabal P., Siegesmund S., Wemmer K., Layer P. 2010. The Sierra Ballena Shear Zone in the southernmost Dom Feliciano Belt (Uruguay): evolution, kinematics and deformation conditions. International Journal of Earth Sciences (Geol. Rundschau) 99, 1227-1246.

Oyhantçabal, P., Siegesmund, S., Wemmer, K., 2011. The Rio de la Plata Craton: a review of units, boundaries, ages and isotopic signature. International Journal of Earth Science 100, 201-220.

Pertille, J., Hartman, L.A., Phillip, R.P. 2015a. Zircon U-Pb age constraints on the Paleoproterozoic sedimentary basement of the Ediacaran Porongos Group, Sul-Riograndense Shield, southern Brazil. Journal of South American Earh Sciences 63, 334-345.

Pertille, J., Hartmann, L.A., Phillip, R.P., Petry, T.S., Lana, C.C., 2015b. Origin of the Ediacaran Porongos Group, Dom Feliciano Belt, southern Brazilian Shield, with emphasis on whole rock and detrital zircon geochemistry and U-Pb, Lu-Hf isotopes. Journal of South American Earth Sciences 64, 69-93.

Petry, T.S., 2014. Evolução do Complexo Porongos na Antiforme Capané com base em mapeamento geológico, petrografia, geoquímica e datação U-Pb em zircão detrítico no USP-SHRIMP IIe. Undergraduate thesis. UFRGS, Porto Alegre, $88 \mathrm{pp}$.

Philipp, R.P., Machado, R., 2005. The Neoproterozoic to Cambrian Granitic Magmatism of Pelotas Batholith, Southern Brazil. Journal of South American Earth Sciences 19, 461-478.

Philip, R.P., Lusa, M., Nardi, L. 2008. Petrology of dioritic, tonalitic and trondhjemitic gneisses from Encantadas Complex, Santana da Boa Vista, southernmost Brazil: Paleoproterozoic continental-arc magmatism. Anais da Academia Brasileira de Ciências 80, 735-748.

Porcher, C.C. 1990. Caracterização das condições de fluxo em uma zona de cisalhamento tangencial na região de Santana da Boa Vista (RS). Msc thesis, Porto Alegre, RS - UFRGS.

Porcher, C.C., Fernandes, L.A.D., 1990. Relações embasamento/"cobertura" na porção ocidental do cinturão Dom Feliciano: um esboço estrutural. Pesquisas, 17, 72-96.

Porcher, C.C., Macnaughton, N.J., Leite, J.A.D., Hartmann, L.A., Fernandes, L.A.D. 1999. Idade SHRIMP do vulcanismo ácido do Complexo Metamórfico Porongos, RS.. In: $1^{\circ}$ SIMPÓSIO SOBRE VULCANISMOS e AMBIENTES ASSOCIADOS, 1999, Gramado. Resumos, 1999. Sociedade Brasileira de Geologia.

Porcher, C.C., Fernandes, L.A.D., Lenz, C., Gruber, L., Vignol, L., Jourdan, F., 2010. Metamorphic ages from Porongos Metamorphic Complex: Rb-Sr and Ar-Ar in muscovite and apatite fission track results. In: VII SSAGI, 2010, Brasilia, pp. 121-124.
Rapela, C.W., Fanning, C.M., Casquet, C., Pankhurst, R.J., Poiré, L.S.D. Baldo, E.G. 2011. The Rio de la Plata craton and the adjoining Pan-African/brasiliano terranes: Their origins and incorporation into south-west Gondwana, Gondwana Research 20, 673-690.

Remus M.V.D., Tedesco, M.A., Philipp R.P., Faccini, U.F. 1987. Evolução estrutural da unidade Porongos a sul do Rio Camaquã, RS. In: Anais Simpósio Sul-Brasileiro de Geologia 3, SBG, Curitiba, Sociedade Brasileira de Geologia Rio de Janeiro, pp. 223-244.

Remus, M.V.D., Philipp, R.P., Faccini, U.F. and Junges, S.L. 1990. Contribução ao estudo geológico-estrutural dos Gnaisses Encantadas e das relacões com as supracrustais Porongos na região de Santana da Boa Vista/RS. In Congresso Brasileiro de Geologia 36, Natal (ed. Sociedade Brasileira de Geologia Rio de Janeiro), pp. 2356-2370.

Remus M.V.D., Hartmann L.A., Ribeiro, M. 1991. Nota sobre a geologia dos metamorfitos de pressão intermediária e granitóides associados da região de Pinheiro Machado/RS. Acta Geologica Leopoldensia 34, 175-190.

Saalmann, K., Remus, M.V.D., Hartmann, L.A. 2006. Structural evolution and tectonic setting of the Porongos belt, southern Brazil. Geological Magazine 143, 59-88.

Saalmann, K., Remus, M.V.D., Hartmann, L.A, Koester, E., Conceição, R.V. 2005. Sm-Nd isotope geochemistry of metamorphic volcano-sedimentary successions in the São Gabriel Block, southernmost Brazil: evidence for the existence of juvenile Neoproterozoic oceanic crust to the east of the Rio de la Plata craton. Precambrian Research 136, 159-175.

Saalmann, K., Gerdes, A., Lahaye, Y., Hartmann, L.A., Remus, M.V.D., Läufer, A. 2010. Multiple accretion at the eastern margin of the Rio de la Plata craton: the prolonged Brasiliano orogeny in southernmost Brazil. International Journal of Earth Sciences 100, 355-378.

Schwartz, J.J., Gromet, L.P. 2004. Provenance of a late Proterozoic early Cambrian basin, Sierras de Córdoba, Argentina. Precambrian Research 129, 1-21.

Silva, L.C., McNaughton, N.J., Hartmann, L.A., Fletcher, I.R. 1997a. U-Pb SHRIMP geochronology in the Camboriú Complex and other gneisses from the basement of the Neoproterozoic (Brasiliano) southern Brazilian granitic province. In II International Symposium on Granites and Associated Mineralizations, Salvador, Brazil, extended abstracts, 1997a, pp. 278-279.

Silva, L.C., McNaughton, J., Hartmann, L.A., Fletcher, I.R., Gresse, P., Scheepers, R. 1997b. U-Pb (SHRIMP) isotopic constraints for the evolution of the southern Brazilian Granitic Province (SBGP) and some correlated South African, PanAfrican plutons. In II International Symposium on Granites and Associated Mineralizations, Salvador, Brazil, extended abstracts, 1997b, pp. 276-277.

Simon, E., Jackson, S.E., Pearsona, N.J., Griffina, W.L., Belousova, E.A. 2004. The application of laser ablationinductively coupled plasma-mass spectrometry to in situ U-Pb zircon geochronology. Chemical Geology 211, 47-69. 
Stacey,J.S., Kramers, J.D. 1975. Approximation of terrestrial lead isotope evolution by a two-stage model. Earth and Planetary Science Letters 26, 207-221.

Taylor, S.R., McLennan, S.M. 1985. The continental crust: its composition and evolution. Blackwell, Oxford, 312 pp.
Tosdal, R.M. 1996. The Amazon-Laurentia connection as viewed from the Middle Proterozoic rocks in the central Andes, western Bolivia and northern Chile. Tectonics, $15,827-842$. 
Supplementary material 1. Laser Ablation ICP-MS U-Pb analyses.

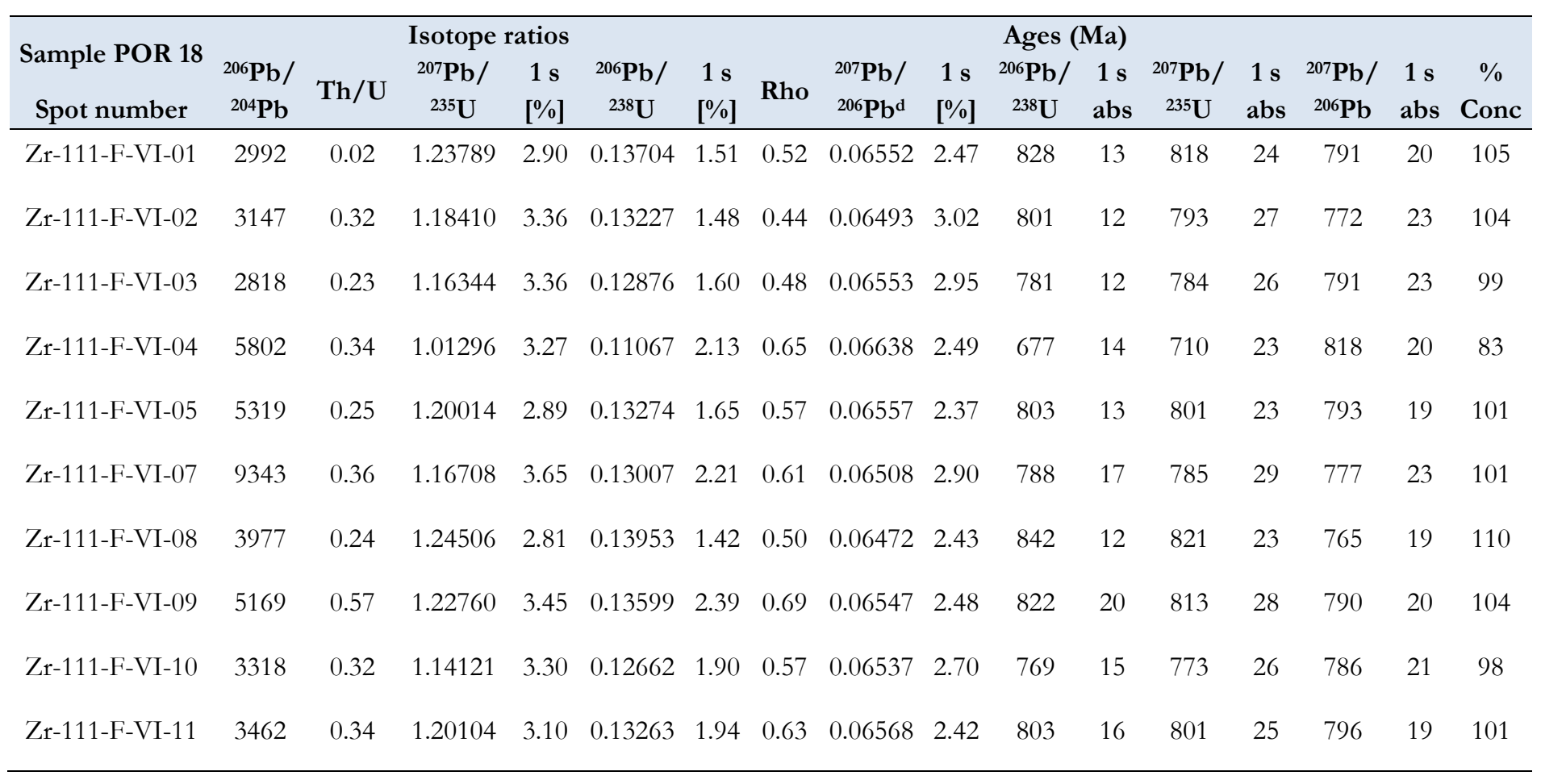


Supplementary material 2. Whole-rock Sm-Nd analyses.

\begin{tabular}{|c|c|c|c|c|c|c|c|c|c|c|}
\hline Sample & $\operatorname{Sm}(\mathrm{ppm})$ & Nd(ppm) & $\begin{array}{c}{ }^{147} \mathrm{Sm} / \\
{ }^{144} \mathrm{Nd}\end{array}$ & $\begin{array}{c}{ }^{143} \mathrm{Nd} / \\
{ }^{144} \mathrm{Nd}\end{array}$ & Error (ppm) & Epsilon Nd (0) & Epsilon Nd (t) & $\boldsymbol{T}_{\mathrm{DM}}$ & ${ }^{143} \mathrm{Nd} /{ }^{144} \mathrm{Nd}(\mathrm{t}=750)$ & $\mathrm{f}(\mathrm{Sm} / \mathrm{Nd})$ \\
\hline POR 04 & 6.37 & 32.03 & 0.12031 & 0.51197 & 43 & -13.0 & -5.7 & 1.73 & 0.51138 & $-0,388335689$ \\
\hline POR 06 & 0.74 & 3.81 & 0.11822 & 0.51208 & 56 & -10.9 & -3.5 & 1.53 & 0.51149 & $-0,398971572$ \\
\hline POR 11 & 5.18 & 27.45 & 0.11398 & 0.51212 & 40 & -10.1 & -2.2 & 1.40 & 0.51156 & $-0,420514416$ \\
\hline POR 12 & 7.26 & 35.58 & 0.12343 & 0.51201 & 39 & -12.3 & -5.3 & 1.73 & 0.51140 & $-0,372492077$ \\
\hline POR 13 & 15.15 & 75.93 & 0.12061 & 0.51199 & 13 & -12.6 & -5.4 & 1.71 & 0.51140 & $-0,386842886$ \\
\hline POR 18 & 2.52 & 12.53 & 0.12165 & 0.51231 & 65 & -6.5 & 0.7 & 1.21 & 0.51171 & $-0,381542281$ \\
\hline RIP 03 & 4.14 & 18.12 & 0.13809 & 0.51176 & 13 & -17.1 & -11.5 & 2.58 & 0.51108 & $-0,297964718$ \\
\hline RIP 05 & 7.42 & 33.49 & 0.13399 & 0.51200 & 35 & -12.4 & -6.4 & 1.98 & 0.51134 & $-0,318817227$ \\
\hline RIP 06 & 0.51 & 2.58 & 0.11923 & 0.51173 & 24 & -17.8 & -10.4 & 2.11 & 0.51114 & $-0,393873079$ \\
\hline RIP 07 & 6.97 & 31.88 & 0.13212 & 0.51199 & 94 & -12.7 & -6.5 & 1.96 & 0.51134 & $-0,328303425$ \\
\hline RIP 09 & 5.02 & 23.40 & 0.12983 & 0.51195 & 13 & -13.4 & -7.0 & 1.97 & 0.51131 & $-0,339937685$ \\
\hline RIP 11 & 0.55 & 2.70 & 0.12307 & 0.51138 & 3 & -24.7 & -17.54 & 2.80 & 0.51077 & $-0,374314446$ \\
\hline RIP 13 & 8.19 & 37.44 & 0.13219 & 0.51182 & 83 & -15.97 & -9.80 & 2281 & 0.51117 & $-0,327966771$ \\
\hline RIP 15 & 8.56 & 40.65 & 0.12731 & 0.51195 & 57 & -13.41 & -6.77 & 1916 & 0.51132 & $-0,352767253$ \\
\hline
\end{tabular}


Supplementary material 3. Whole-rock $\mathrm{Pb}-\mathrm{Pb}$ analyses.

\begin{tabular}{|c|c|c|c|c|c|c|c|c|c|c|}
\hline Sample name & $\begin{array}{c}{ }^{206} \mathrm{~Pb} / \\
{ }^{204} \mathrm{~Pb}\end{array}$ & SE $(\%)$ & $\begin{array}{l}{ }^{207} \mathrm{~Pb} / \\
{ }^{204} \mathrm{~Pb}\end{array}$ & SE $(\%)$ & $\begin{array}{c}{ }^{208} \mathrm{~Pb} / \\
{ }^{204} \mathrm{~Pb}\end{array}$ & SE $(\%)$ & $\begin{array}{c}{ }^{208} \mathrm{~Pb} / \\
{ }^{206} \mathrm{~Pb}\end{array}$ & SE $(\%)$ & $\begin{array}{c}{ }^{207} \mathrm{~Pb} / \\
{ }^{206} \mathrm{~Pb}\end{array}$ & SE (\%) \\
\hline POR 04 & 19.37561 & 0.0083 & 15.74699 & 0.0075 & 39.83039 & 0.0075 & 2.05567 & 0.0023 & 0.81272 & 0.0016 \\
\hline POR 06 & 19.19231 & 0.0042 & 15.73182 & 0.0054 & 39.89286 & 0.0040 & 2.07867 & 0.0017 & 0.81973 & 0.0015 \\
\hline POR 11 & 19.88524 & 0.0078 & 15.78905 & 0.0062 & 40.35159 & 0.0072 & 2.02918 & 0.0038 & 0.79399 & 0.0014 \\
\hline POR 12 & 18.81813 & 0.0049 & 15.72727 & 0.0049 & 39.05199 & 0.0051 & 2.07522 & 0.0010 & 0.83575 & 0.0007 \\
\hline POR 13 & 19.13910 & 0.0009 & 15.74474 & 0.0018 & 39.54444 & 0.0024 & 2.06614 & 0.0019 & 0.82263 & 0.0015 \\
\hline POR 18 & 20.01847 & 0.0258 & 15.82259 & 0.0260 & 39.95011 & 0.0246 & 1.99565 & 0.0030 & 0.79038 & 0.0040 \\
\hline RIP 03 & 19.61483 & 0.0029 & 15.93771 & 0.0026 & 40.84595 & 0.0042 & 2.08257 & 0.0003 & 0.81244 & 0.0002 \\
\hline RIP 05 & 20.01148 & 0.0018 & 15.94995 & 0.0016 & 40.31886 & 0.0026 & 2.01493 & 0.0002 & 0.79694 & 0.0002 \\
\hline RIP 06 & 19.01235 & 0.0017 & 15.74994 & 0.0016 & 38.79429 & 0.0025 & 2.04064 & 0.0002 & 0.82814 & 0.0002 \\
\hline RIP 07 & 19.71898 & 0.0017 & 15.78861 & 0.0015 & 39.60218 & 0.0025 & 2.00847 & 0.0002 & 0.80058 & 0.0002 \\
\hline RIP 09 & 18.55247 & 0.0013 & 15.68252 & 0.0012 & 38.68988 & 0.0020 & 2.08561 & 0.0002 & 0.84525 & 0.0001 \\
\hline RIP 11 & 19.27950 & 0.0018 & 15.74303 & 0.0017 & 38.48995 & 0.0027 & 1.99657 & 0.0002 & 0.81649 & 0.0001 \\
\hline RIP 13 & 19.78336 & 0.0030 & 15.79877 & 0.0027 & 41.59954 & 0.0044 & 2.10292 & 0.0003 & 0.79849 & 0.0002 \\
\hline RIP 15 & 18.60428 & 0.0015 & 15.74809 & 0.0014 & 39.55200 & 0.0022 & 2.12615 & 0.0002 & 0.84641 & 0.0001 \\
\hline
\end{tabular}

